John S. Kloppenborg

\title{
Synoptic Problems
}

Collected Essays

[Synoptische Probleme. Gesammelte Aufsätze.]

Veröffentlicht auf Englisch.

Dieser Band versammelt einundzwanzig Aufsätze von John S. Kloppenborg, die vier Schwerpunkte haben: konzeptuelle und methodologische Fragen bezüglich des Synoptischen Problems, das Spruchevangelium Q, das Markusevangelium, und die Gleichnisse Jesu. Kloppenborg, ein Experte auf dem Gebiet des Synoptischen Problems, interessiert sich vor allem dafür, wie man synoptische Hypothesen aufstellen kann und sich dabei immer der vielen Wissenslücken, der konkurrierenden Hypothesen und der theologischen und historischen Folgerungen jeder Hypothese bewusst ist. Die Aufsätze der letzten drei Kapitel haben gemein, dass sie voraussetzen, dass Literatur, Denken und Praxis der frühen Jesusbewegung mit dem Wissen um ihren sozialen, literarischen und intellektuellen Kontext betrachtet werden müssen. Der Kontext der Jesusbewegung wird nicht nur durch den Rückgriff auf literarische und historische Quellen, die aus der griechischen und der römischen Elite stammen, beleuchtet, sondern auch durch Informationen aus nicht literarischen Papyri.

Inhaltsübersicht

Preface - Introduction - Abbreviations

I. Synoptic ProblemsThe Theological Stakes in the Synoptic Problem - Is There a New Paradigm? - On Dispensing with Q? Goodacre on the Relation of Luke to Matthew - Variation in the Reproduction of the Double Tradition and an Oral Q? Synopses and the Synoptic Problem

2014. XIII, 737 Seiten. WUNT I 329

II. The Sayings Gospel Q Symbolic Eschatology and the Apocalypticism of Q - »Easter Faith « and the Sayings Gospel Q - Nomos and Ethos in Q - City and Wasteland: Narrative World and the Beginning of the Sayings Gospel (Q) - Literary Convention, SelfEvidence, and the Social History of the Q People - The Sayings Gospel Q: Literary and Stratigraphic Problems - A Dog Among the Pigeons: The Cynic Hypothesis as a Theological Problem - Discursive Practices in the Sayings Gospel Q and the Quest of the Historical Jesus

DOI 10.1628/978-3-16-153273-3

eBook PDF $229,00 €$

ISBN 978-3-16-152617-6

Leinen $229,00 €$

III. The Gospel of Mark Egyptian Viticultural Practices and the Citation of Isa 5:1-7 in Mark 12:1-9 - Self-Help or Deus ex Machina in Mark 12.9? - Evocatio Deorum and the Date of Mark - Agrarian Discourse in the Sayings of Jesus

IV. Parablesjesus and the Parables of Jesus in Q - The Parable of the Prodigal Son and Deeds of Gift - Pastoralism, Papyri and the Parable of the Shepherd - The Representation of Violence in the Synoptic Parables

John S. Kloppenborg Born 1951; MA and PhD at the University of St. Michael's College; Professor and Chair of the Department for the Study of Religion, University of Toronto.

Jetzt bestellen:

https://mohrsiebeck.com/buch/synoptic-problems-9783161532733?no_cache=1

order@mohrsiebeck.com

Telefon: +49 (0)7071-923-17

Telefax: +49 (0)7071-51104

Mohr Siebeck GmbH \& Co. KG

Postfach 2040

D-72010 Tübingen

info@mohrsiebeck.com

Mohr Siebeck 